\title{
Hukum Waris Islam Di Indonesia (Studi Perkembangan Hukum Kewarisan Dalam Kompilasi Hukum Islam Dan Praktek Di Pengadilan Agama )
}

\author{
Syarief Husien*, Akhmad Khisni** \\ Mahasiswa Program Magister (S2) Kenotariatan Fakultas Hukum UNISSULA, Semarang \\ * Dosen Fakultas Hukum UNISSULA
}

\begin{abstract}
ABSTRAK
Penelitian dengan judul "Hukum Waris Islam Di Indonesia (Studi Perkembangan Hukum Kewarisan Dalam Kompilasi Hukum Islam Dan Praktek Di Pengadilan Agama)'Penelitian ini menggunakan pendekatan yuridis normative, dalam pengumpulan data lebih ditekankan pada sumber bahan primer, berupa peraturan perundang-undangan, menelaah kaidah-kaidah hukum maupun teori ilmu hukum yang terkait dengan masalah yang di teliti.

Berdasarkan metode tersebut penelitian menghasilkan pada pokoknya : (1) Formulasi hukum kewarisan islam dalam fiqih dan Kompilasi Hukum Islam (a) Formulasi hukum kewarisan Islam dalam fiqih pada al quran dan al hadist yaitu : Al quran, QS. An-nisa (4): 7, QS. An-nisa (4): 11, QS. An-nisa (4): 12, QS. Annisa (4): 33, QS. An-nisa (4): 176, QS. Al-anfal (8): 75, dan Hadist Rasulullah SAW (b) Formulasi hukum kewarisan Islam dalam Kompilasi Hukum Islam di atur dalam Pasal 171 sampai dengan Pasal 193.(2) Perkembangan hukum kewarisan Islam dalam Kompilasi Hukum Islam di banding dengan kewarisan dalam fiqih yaitu banyak memasukkan unsur-unsur hukum adat dan kepentingan-kepentingan yang dibutuhkan masyarakat Indonesia masa sekarang, maka banyak bentuk-bentuk hukum kewarisan yang belum tertuang dalam fiqh konvensional (fiqh al-mawarits), namun hal itu telah termuat dan terkodifikasikan dalam hukum kewarisan Kompilasi Hukum Islam, antara lain: pasal 171 tentang harta bersama, pasal 177 tentang pembagian ayah secara 'ashabah, pasal 209 yang menyatakan bahwa ayah angkat dan anak angkat menerima warisan, dan bila mereka tidak menerima wasiat, maka berhak menerima wasiat wajibah dan Kopilasi Hukum Islam pun mengakui harta gono-gini padahal fiqh tidak mengakui; (3) Perkembangan hukum kewarisan Islam dalam praktek putusan pengadilan agama di Indonesia hal ini tidak lepas dari Kompilasi Hukum Islam merupakan intruksi Presiden No. 1 Tahun 1991 tanggla 10 Juni 1991, sehingga perkawinan, kewarisan, dan wakaf bagi pemeluk-pemeluk Islam telah ditetapkan sehingga dapat dijadikan pengadilan agama sebagai "pedoman" dalam artian sebagai sesuatu petunjuk bagi para hakim Peradilan Agaman dalam memutus dan menyelesaikan perkara, maka kedudukannya adalah tergantung sepenuhnya dari para Hakim dimaksud untuk menuangkannya dalam keputusan-keputusan mereka masing-masing sehingga kompilasi ini akan terwujud dan mempunyai makna serta landasan yang kokoh dalam yurisprudensi Peradilan Agama. Dengan cara demikian, maka Peradilan Agama tidak hanya berkewajiban menerapkan ketentuan-ketentuan yang sudah digariskan dalam kompilasi, akan tetapi justru mempunya peranan yang lebih besar lagi untuk memperkembangkan dan sekaligus melengkapinya melalui yurisprudensi yang dibuatnya.

Kata kunci : Hukum waris Islam, hukum Kewarisan, Kompilasi Hukum Islam
\end{abstract}

\begin{abstract}
The research entitled "The Law of Inheritance of Islam in Indonesia (Study of Legal Development of Inheritance in Compilation of Islamic Law and Practice in Religious Courts)" This research uses normative juridical approach, in collecting data more emphasized on primary source material, in the form of legislation, - the rule of law and the theory of jurisprudence associated with the problem in the perusal.

Based on these methods, the research produces basically: (1) Formulation of Islamic inheritance law in fiqh and Compilation of Islamic Law (a) Formulation of Islamic inheritance law in fiqih on al quran and al-hadist namely: Al Quran, QS. An-nisa (4): 7, QS. An-nisa (4): 11, QS. An-nisa (4): 12, QS. An-nisa (4): 33, QS. Annisa (4): 176, QS. Al-anfal (8): 75, and Hadith Rasulullah SAW (b) The formulation of Islamic inheritance law in the Compilation of Islamic Law is set in Articles 171 to 193. (2) The development of Islamic inheritance law in the Compilation of Islamic Law in appeal to inheritance in fiqih which includes many elements of customary law and the interests that are needed by Indonesian society today, so many forms of inheritance law that has not been contained in the conventional fiqh (figh al-mawarits), but it has been contained and codified in the law of inheritance The Compilation of Islamic Law, among others: article 171 on common property, article 177 on the division of fathers asabah, article 209 which states that foster and adopted sons
\end{abstract}


receive inheritance, and if they do not receive a will, it is entitled to a mandatory and compulsory law Islam also recognizes the property gono-gini fiqh although do not recognize; (3) The development of Islamic inheritance law in the practice of religious court ruling in Indonesia is not separated from the Compilation of Islamic Law is the Presidential Instruction. 1 In 1991 on 10 June 1991, so that marriage, inheritance and endowments for the followers of Islam have been established so that it can be used as religious courts as a "guide" in the sense that a guide for the judges of the Religious Court in deciding and settling the case, depends entirely from the Judges intended to put it in their respective decisions so that this compilation will materialize and have a firm meaning and foundation in the jurisprudence of the Religious Courts. In this way, the Religious Judiciary is not only obliged to apply the provisions outlined in the compilation, but it has a greater role to develop and at the same time complete it through the jurisprudence it makes.

Keywords: Islamic inheritance law, law of Inheritance, Compilation of Islamic Law

\section{PENDAHULUAN}

Pelaksanaan hukum Islam di Indonesia, secara ringkas, mengalami fase yang cukup panjang semenjak zaman kolonial Belanda hingga zaman perubahan ini. Sejarah membuktikan bahwa aplikasi hukum Islam dalam tatanan keindonesiaan baru teraplikasikan dalam UU No. 1 tahun 1974 tentang perkawinan dan dalam UU No. 7 tahun 1989 tentang peradilan itu pun dengan perjuangan yang "melelahkan" khususnya bagi umat Islam. ${ }^{1}$

Adapun sumber hukum yang dijadikan pedoman bagi para penegak hukum (Hakim), Praktisi, dan sebagainya selain undang-undang tertulis tersebut di atas adalah fatwa-fatwa ulama, baik yang tertulis dalam kitab-kitab fiqh klasik ataupun kitab-kitab fiqh modern. Sumber-sumber tersebut sampai hari ini merupakan bahan pelengkap dalam proses pengalian Hukum Islam.

Dengan demikian, hukum mengalami pertumbuhan dan perkembangan tanpa dapat dihindari, karena secara internal hukum menuntut dirinya untuk diinterpretasi walau dengan varianvarian dan tingkat yang berbeda.

Walaupun disebutkan oleh Baqir S. Manan ${ }^{2}$ bahwa interpretasi terhadap kaidah-kaidah hukum dapat dilakukan oleh kekuasaan kehakiman, legislatif dan eksekutif. Hal ini untuk menghindari kerancuan interpretasi akibat perbedaan pemikiran dan kemampuan masing-masing penegak hukum. Namun kondisi dimana tidak adanya pedoman hukum yang baku dan komprehensif bagi para praktisi hukum (baik formal maupun non-formal) selain kedua undang-undang diatas, dengan sendirinya akan melahirkan berbagai penafsiran dan pemahaman yang berbeda bahkan kontroversial.

\footnotetext{
1 Abdul Gani Abdullah, 1992, Pengantar Kompilasi Hukum Islam dalam Tata Hukum Indonesia,Gema Insani Press, Jakarta, h. 35.

2 Bagir Manan, 1995, Pertumbuhan dan Perkembangan Konstitusi Suatu Negara, Mandar Maju Bandung, h. 10.
}

Upaya pembaruan dalam bentuk kodifikasi dan unifikasi hukum itu, khususya hukum keperdataan seperti waris, munakahat, dan lain sebagainya muncul ketika lahirnya Kompilasi Hukum Islam di Indonesia. Hukum-hukum tersebut telah mengalami perubahan baik status hukum ataupun dalam prakteknya.

KHI yang tertuang dalam Instruksi Presiden Nomor 1 tahun 1991, dan dilaksanakan dengan Keputusan Menteri Agama Nomor 154 tahun 1991. Menurut para pakar hukum Islam seperti Rachmat Djatnika, Abdul Gani Abdullah, Bustanul Arifin, dan lain sebagainya, KHI merupakan hukum positif Islam untuk melaksanakan peraturan perundangundangan yang berlaku. Ia memiliki konsistensi dengan peraturan perundang-undangan yang kedudukannya lebih tinggi dan dijadikan sebagai rujukan bagi para penegak hukum. ${ }^{3}$

Pada tataran sistematika hukum, perubahan hukum, menurut pandangan Fazlur Rahman, ${ }^{4}$ memiliki tiga lapis pendekatan:

1. Pendekatan historis yang sederhana dan jujur dalam menemukan makna teks al-Qur'an. Pertama-tama, al-Qur'an harus ditelaah dalam susunan yang kronologis dengan pengujian terhadap wahyu-wahyu paling awal, kemudian;

2. Membedakan antara diktum hukum al-Qur'an, sasaran dan tujuan hukum hukum itu

3. Sasaran al-Qur'an harus dipahami, diramu, dan memperhatikan setting sosiologis dimana Nabi bergerak dan bekerja.

Berbeda pandangan dengan Rahman, AnNaim, ${ }^{5}$ menjelaskan bahwa pola perubahan bisa dimulai dengan pendekatan deduktif dan induktif dari masalah agama dan moral ke masalah politik

3 Cik Hasan Bisri, 1996, Dimensi-dimensi Kompilasi Hukum Islam, Ulul Albab Press, Bandung, h. 13.

4 Fazlur Rahman, 1994, Islam (Terj.), Salman ITB, Bandung, h. 67.

5 Abdullah An-Naim, 1994, Toward an Islamic Reformation Cil Liberties, Human Rights and International Law(diterjemahkan oleh Ahmad Suaedy dan Amiruddin Arrani), Dekonstruksi Syari'ah, LkiS, Yogyakarta, h. 28. 
dan hukum, melainkan pula perubahan dalam makna dan implikasi al-Qur'an dan al-Sunnah.

Selanjutnya, Juhaya S. Praja menuturkaaan pada wilayah hukum terbagi kepada dua; wilayah insaniyah dan wilayah uluhiyah. Wilayah insaniyah tertumpu pada aspek-aspek kemanusiaan seperti: sikap, sifat, dan prilaku manusia. Misalnya; Hakim tidak boleh memutuskan perkara ketika sedang marah. Kata marah, dapat diinterpretasikan dengan berbagai argumentasi sepanjang aspekaspek kemanusiaannya ada. Sedangkan wilayah uluhiyah adalah berupa doktrin atau dogma yang termaktub dalam al-Qur'an. Dengan penjelasan tersebut, KHI, bila disorot dengan kajian wilayah, ia termasuk pada wiayah insaniyah karena berupa pemikiran-pemikiran manusia yang terhimpun, kemudian dilegalisasi menjadi peraturan. Bahkan menurut A. Djazuli, KHI ini dibuat oleh dua kekuatan besar masyarakat Indonesia. Masyarakat ulama dan masyarakat umara. Dari dua kekuatan inilah akhirnya berhasil memunculkan suatu produk hukum yang termuat dalam KHI sebagai pegangan para hakim di lingkungan Peradilan Agama sekaligus bagi masyarakat yang membutuhkannya. ${ }^{6}$

Pada tataran metode, perubahan hukum, menurut para pakar hukum Islam tidak terlepaskan kepada metode istislah, 'urf, qiyas dan istihsan-dua metode yang terakhir termasuk cara penafsiran hukum berdasarkan penalaran logis atas suatu 'illat hukum, ratio logis. Metode ini, secara faktual epektif, akan tetapi ia juga melahirkan perbedaan sangat besar di kalangan para ahli hukum karena perbedaan pandangan dalam menentukan dan menguji 'illat hukum yang sesungguhnya. Dalam banyak kasus penalaran tersebut (terutama qiyas) melahirkan varian-varian hukum yang idealistik dan tidak sosiologis. ${ }^{7}$

Problem metodologis ini berupaya dipecahkan oleh ahli-ahli hukum lainnya, seperti Al-Ghazali, dengan penawaran metode istislahi yang lebih etis dan pragmatis. Kemudian metode ini dikembangkan oleh al-Syatibi. Melalui karya monumentalnya (al-muwafaqat), ia secara genial berupaya merumuskan sebuah pendekatan metodologis yang didasarkan pada tujuan-tujuan syari'ah (maqashid al-Syari'ah).

\footnotetext{
6 A. Djazuli, Beberapa Aspek Pengembangan Hukum Islam di Indonesia, dalam Eddi Rudiana Arief, et. Al. (ED). 1991, Hukum Islam di Indonesia Pemikiran dan Praktek, Rosdakarya, Bandung, h. 235-236.

7 Ahmad Hasan, 1994, The early Development of Islamic Yurisprudence (terj.),Kitab Bhavan, New Delhi, h. 97.
}

Begitu halnya dengan KHI, metode yang dikedepankan adalah metode istislah atau maslahat. Hal itu terbukti dari materi kewarisan terutama pada point angka 4, disampng juga menggunakan metode qiyas dan istihsan.

Bahwa meskipun KHI sudah dianggap sebagai hukum positif bagi umat islam di indonesia akan tetapi dalam pelaksanaan pembagian waris di beberapa kalangan umat Islam tidak mengunakan dasar KHI melainkan mengunakan ketentuan syariah, oleh karenannya hal ini juga menimbulkan persoalan tersendiri di kalangan masyarakat terkait pembagian harta warisan.

Peradilan agama yang merupakan peradilan bagi umatIslam untuk memutuskan segala persolaan keperdataan umat Islam yang salah satunya adalah persolan kewarisan harus bias menjawab serta memutuskan segala persoalaan tersebut dengan adil bagi umat Islam yang tentunya mengikuti segala perkembangan hukum waris Islam yang ada di Indonesia dengan harapan tidak ada gejolak di masyarakat.

Berdasarkan permasalahan di atas maka penulis melakukan penelitan dengan judul "Hukum Waris Islam Di Indonesia (Studi Perkembangan Hukum Kewarisan Dalam Kompilasi Hukum Islam Dan Praktek Di Pengadilan Agama )

\section{Metode Penelitian}

Metode penelitian yang digunakan dalam penelitian ini yuridis normatif dengan pendekatan undang-undang (statute approach), pendekatan kasus (case approach), pendekatan historis (historical approach), pendekatan komparatif (comparative approach), dan pendekatan konseptual (conceptual approach). ${ }^{8}$

\section{HASIL PENELITIAN DAN PEMBAHASAN}

\section{Formulasi Hukum Kewarisan Islam Dalam Fiqih Dan Kompilasi Hukum Islam}

Formulasi hukum kewarisan Islam dalam fiqih mendasarkan pada al quran dan al hadist yaitu :

a) Al quran

1) QS. An-nisa (4): 7

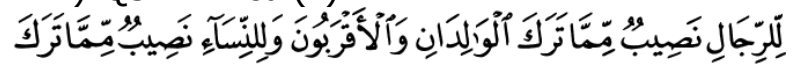

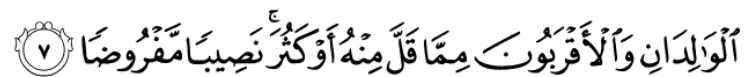
Artinya : Bagi orang laki-laki ada hak bagian dari harta peninggalan ibu-bapa dan kerabatnya, dan bagi orang wanita ada hak bagian (pula) dari harta peninggalan ibu-bapa

$8 \quad$ Ibid. h. 93 
dan kerabatnya, baik sedikit atau banyak menurut bahagian yang telah ditetapkan

2) QS. An-nisa (4): 11

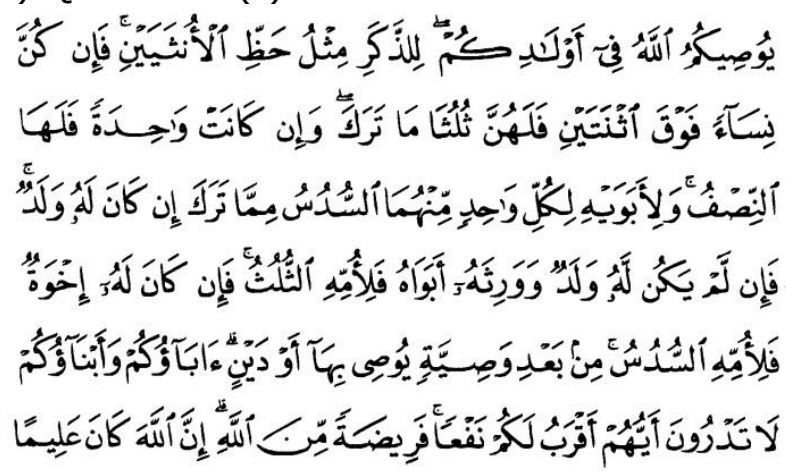

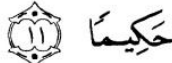

Artinya : Allah mensyari'atkan bagimu tentang (pembagian pusaka untuk) anak-anakmu. Yaitu: bahagian seorang anak lelaki sama dengan bagahian dua orang anak perempuan; dan jika anak itu semuanya perempuan lebih dari dua, maka bagi mereka dua pertiga dari harta yang ditinggalkan; jika anak perempuan itu seorang saja, maka ia memperoleh separo harta. Dan untuk dua orang ibu-bapa, bagi masing-masingnya seperenam dari harta yang ditinggalkan, jika yang meninggal itu mempunyai anak; jika orang yang meninggal tidak mempunyai anak dan ia diwarisi oleh ibu-bapanya (saja), maka ibunya mendapat sepertiga; jika yang meninggal itu mempunyai beberapa saudara, maka ibunya mendapat seperenam. (Pembagian-pembagian tersebut di atas) sesudah dipenuhi wasiat yang ia buat atau (dan) sesudah dibayar hutangnya. (Tentang) orang tuamu dan anak-anakmu, kamu tidak mengetahui siapa di antara mereka yang lebih dekat (banyak) manfaatnya bagimu. Ini adalah ketetapan dari Allah. Sesungguhnya Allah Maha Mengetahui lagi Maha Bijaksana

3) QS. An-nisa (4): 12

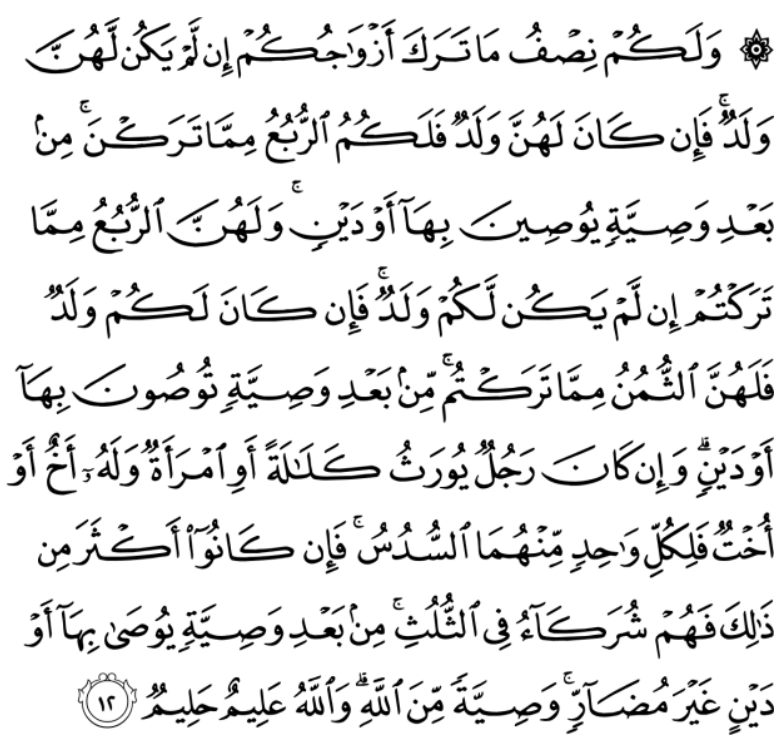

Artinya : Dan bagimu (suami-suami) seperdua dari harta yang ditinggalkan oleh isteri-isterimu, jika mereka tidak mempunyai anak. Jika isteriisterimu itu mempunyai anak, maka kamu mendapat seperempat dari harta yang ditinggalkannya sesudah dipenuhi wasiat yang mereka buat atau (dan) seduah dibayar hutangnya. Para isteri memperoleh seperempat harta yang kamu tinggalkan jika kamu tidak mempunyai anak. Jika kamu mempunyai anak, maka para isteri memperoleh seperdelapan dari harta yang kamu tinggalkan sesudah dipenuhi wasiat yang kamu buat atau (dan) sesudah dibayar hutang-hutangmu. Jika seseorang mati, baik laki-laki maupun perempuan yang tidak meninggalkan ayah dan tidak meninggalkan anak, tetapi mempunyai seorang saudara lakilaki (seibu saja) atau seorang saudara perempuan (seibu saja), maka bagi masingmasing dari kedua jenis saudara itu seperenam harta. Tetapi jika saudara-saudara seibu itu lebih dari seorang, maka mereka bersekutu dalam yang sepertiga itu, sesudah dipenuhi wasiat yang dibuat olehnya atau sesudah dibayar hutangnya dengan tidak memberi mudharat (kepada ahli waris). (Allah menetapkan yang demikian itu sebagai) syari'at yang benar-benar dari Allah, dan Allah Maha Mengetahui lagi Maha Penyantun

4) QS. An-nisa (4): 33

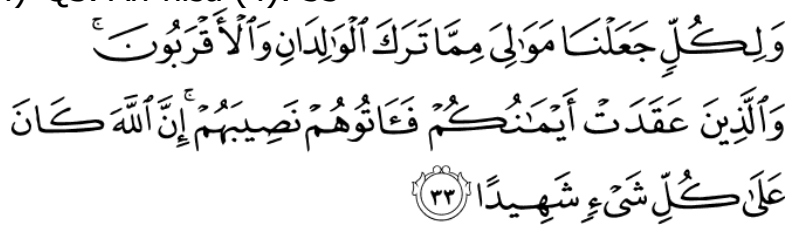


Artinya : Bagi tiap-tiap harta peninggalan dari harta yang ditinggalkan ibu bapak dan karib kerabat, Kami jadikan pewaris-pewarisnya. Dan (jika ada) orang-orang yang kamu telah bersumpah setia dengan mereka, maka berilah kepada mereka bahagiannya. Sesungguhnya Allah menyaksikan segala sesuatu.

5) QS. An-nisa (4): 174

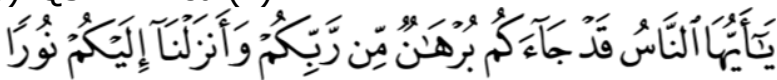

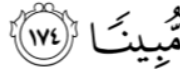

Artinya : Hai manusia, sesungguhnya telah datang kepadamu bukti kebenaran dari Tuhanmu. (Muhammad dengan mukjizatnya) dan telah Kami turunkan kepadamu cahaya yang terang benderang (Al Quran)

6) QS. Al-anfal (8): 75

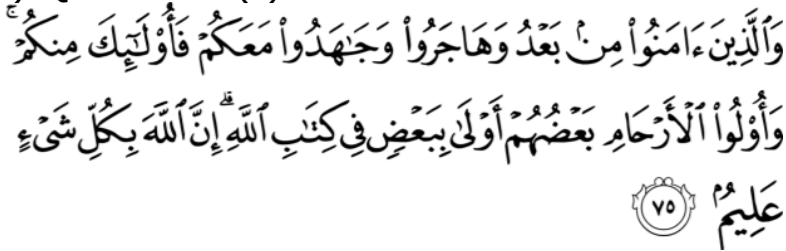

Artinya : Dan orang-orang yang beriman sesudah itu kemudian berhijrah serta berjihad bersamamu maka orang-orang itu termasuk golonganmu (juga). Orang-orang yang mempunyai hubungan kerabat itu sebagiannya lebih berhak terhadap sesamanya (daripada yang bukan kerabat) di dalam kitab Allah. Sesungguhnya Allah Maha Mengetahui segala sesuatu

b) Hadist Rasulullah SAW

1) Hadist Nabi dari Ibn Abbas menurut riwayat AlBukhari

"Dari Ibnu Abbas dia berkata: Rasulullah bersabda: berikan bagian-bagiam warisan kepada ahli warisnya, selebihnya kepada lakilaki yang dekat".

2) Hadist Nabi dari Jabir Bin 'Abdillah yang berbunyi:

Dari Jabir Bin 'Abdillah berkata: janda Sa'ad datang kepada Rasulallah SAW, bersama dua anak perempuannya. Lalu ia berkata: "Ya Rasulallah, ini dua anak perempuan Sa'ad yang

9 Al-Hafidh Ibnu Hajar AL-Asqalani, 1995, Bulughul Maram, Ali, Terjemah Bulughul Maram, Mutiara Ilmu, Surabaya, h. 403. telah gugur secara syahid bersamamu di perang Uhud. Paman mereka mengambil harta peninggalan ayah mereka dan tidak memberikan apa-apa untuk mereka. Keduanya tidak dapat kawan tanpa harta". Nabi berkata: "Allah akan menetapkan hukum dalam kejadian ini". Kemudian ayat-ayat tentang kewarisan. Nabi memanggil si paman dan berkata: "Berikan dua pertiga untuk untuk dua orang anak Sa'ad, seperlapan untuk istri Sa'ad dan selebihnya ambil untukmu".10

\section{Formulasi Hukum Kewarisan Islam Dalam Kompilasi Hukum Islam}

Formulasi hukum kewarisan dalam Kompilasi Hukum Islam di atur dalam Pasal 171 sampai dengan Pasal 193.

Pasal 171

Yang dimaksud dengan:

a. Hukum kewarisan adalah hukum yang mengatur tentang pemindahan hak pemilikan harta peninggalan (tirkah) pewaris, menentukan siapa-siapa yang berhak menjadi ahli waris dan berapa bagiannya masing-masing.

b. Pewaris adalah orang yang pada saat meninggalnya atau yang dinyatakan meninggal berdasarkan putusan Pengadilan beragama Islam, meninggalkan ahli waris dan harta peninggalan.

c. Ahli waris adalah orang yang pada saat meninggal dunia mempunyai hubungan darah atau hubungan perkawinan dengan pewaris, beragama Islam dan tidak terhalang karena hukum untuk menjadi ahli waris.

d. Harta peninggalan adalah harta yang ditinggalkan oleh pewaris baik yang berupa benda yang menjadi miliknya maupun hakhaknya.

e. Harta waris adalah harta bawaan ditambah bagian dari harta bersama setelah digunakan untuk keperluan pewaris selama sakit sampai meninggalnya, biaya pengurusan jenazah (tajhiz), pembayaran hutang dan pemberian untuk kerabat.

f. Wasiat adalah pemberian suatu benda dari pewaris kepada orang lain atau lembaga yang akan berlaku setelah pewaris meninggal dunia.

g. Hibah adalah pemberian suatu benda secara sukarela dan tanpa imbalan dari seseorang kepada orang lain yang masih hidup untuk dimiliki.

10 Jabir Bin Abu Dawud, al-Tirmizi, Ibnu Majjah dan Ahmad, 1952, Sunanu Abi Dawud II, Mustafa al Babiy, Cairo, h. 109. 
h. Anak angkat adalah anak yang dalam pemeliharaan untuk hidupnya sehari-hari, biaya pendidikan dan sebagainya beralih tanggung jawabnya dari orang tua asal kepada orang tua angkatnya berdasarkan putusan Pengadilan.

i. Baitul Mal adalah Balai Harta Keagamaan.

\section{Pasal 172}

Ahli waris dipandang beragama Islam apabila diketahui dari Kartu Identitas atau pengakuan atau amalan atau kesaksian, sedangkan bagi bayi yang baru lahir atau anak yang belum dewasa, beragama menurut ayahnya atau lingkungannya.

Pasal 173

Seorang terhalang menjadi ahli waris apabila dengan putusan hakim yang telah mempunyai kekuatan hukum yang tetap, dihukum karena:

a. dipersalahkan telah membunuh atau mencoba membunuh atau menganiaya berat para pewaris;

b. dipersalahkan secara memfitnah telah mengajukan pengaduan bahwa pewaris telah melakukan suatu kejahatan yang diancam dengan hukuman 5 tahun penjara atau hukuman yang lebih berat.

Pasal 174

(1) Kelompok-kelompok ahli waris terdiri dari:

a. Menurut hubungan darah:

- golongan laki-laki terdiri dari : ayah, anak laki-laki, saudara laki-laki, paman dan kakek.

- golongan perempuan terdiri dari : ibu, anak perempuan, saudara perempuan dari nenek.

b. Menurut hubungan perkawinan terdiri dari : duda atau janda.

(2) Apabila semua ahli waris ada, maka yang berhak mendapat warisan hanya: anak, ayah, ibu, janda atau duda.

Pasal 175

(1) Kewajiban ahli waris terhadap pewaris adalah:

a. mengurus dan menyelesaikan sampai pemakaman jenazah selesai;

b. menyelesaikan baik hutang-hutang berupa pengobatan, perawatan, termasuk kewajiban pewaris maupun penagih piutang;

c. menyelesaikan wasiat pewaris;

d. membagi harta warisan di antara wahli waris yang berhak.
(2) Tanggung jawab ahli waris terhadap hutang atau kewajiban pewaris hanya terbatas pada jumlah atau nilai harta peninggalannya.

\section{Pasal 176}

Anak perempuan bila hanya seorang ia mendapat separoh bagian, bila dua orang atau lebih mereka bersama-sama mendapat dua pertiga bagian, dan apabila anak perempuan bersama-sama dengan anak laki-laki, maka bagian anak laki-laki adalah dua berbanding satu dengan anak perempuan.

\section{Pasal 177}

Ayah mendapat sepertiga bagian bila pewaris tidak meninggalkan anak, bila ada anak, ayah mendapat seperenam bagian. *

\section{Pasal 178}

(1) Ibu mendapat seperenam bagian bila ada anak atau dua saudara atau lebih. Bila tidak ada anak atau dua orang saudara atau lebih, maka ia mendapat sepertiga bagian.

(2) Ibu mendapat sepertiga bagian dari sisa sesudah diambil oleh janda atau duda bila bersama-sama dengan ayah.

\section{Pasal 179}

Duda mendapat separoh bagian, bila pewaris tidak meninggalkan anak, dan bila pewaris meninggalkan anak, maka duda mendapat seperempat bagian.

\section{Pasal 180}

Janda mendapat seperempat bagian bila pewaris tidak meninggalkan anak, dan bila pewaris meninggalkan anak maka janda mendapat seperdelapan bagian.

\section{Pasal 181}

Bila seorang meninggal tanpa meninggalkan anak dan ayah, maka saudara laki-laki dan saudara perempuan seibu masing-masing mendapat seperenam bagian. Bila mereka itu dua orang atau lebih maka mereka bersamasama mendapat sepertiga bagian.

Pasal 182

Bila seorang meninggal tanpa meninggalkan anak dan ayah, sedang ia mempunyai satu saudara perempuan kandung atau seayah, maka ua mendapat separoh bagian. Bila saudara perempuan tersebut bersama-sama dengan saudara perempuan kandung atau seayah dua 
orang atau lebih, maka mereka bersama-sama mendapat dua pertiga bagian.

Bila saudara perempuan tersebut bersama-sama dengan saudara laki-laki kandung atau seayah, maka bagian saudara laki-laki dua berbanding satu dengan saudara perempuan.

Pasal 183

Para ahli waris dapat bersepakat melakukan perdamaian dalam pembagian harta warisan, setelah masing-masing menyadari bagiannya.

Pasal 184

Bagi ahli waris yang belum dewasa atau tidak mampu melaksanakan hak dan kewajibannya, maka baginya diangkat wali berdasarkan keputusan Hakim atas usul anggota keluarga.

Pasal 185

(1) Ahli waris yang meninggal lebih dahulu dari pada sipewaris maka kedudukannya dapat digantikan oleh anaknya, kecuali mereka yang tersebut dalam Pasal 173.

(2) Bagian ahli waris pengganti tidak boleh melebihi dari bagian ahli waris yang sederajat dengan yang diganti.

Pasal 186

Anak yang lahir di luar perkawinan hanya mempunyai hubungan saling mewaris dengan ibunya dan keluarga dari pihak ibunya.

Pasal 187

(1) Bilamana pewaris meninggalkan warisan harta peninggalan, maka oleh pewaris semasa hidupnya atau oleh para ahli waris dapat ditunjuk beberapa orang sebagai pelaksana pembagian harta warisan dengan tugas:

a. mencatat dalam suatu daftar harta peninggalan, baik berupa benda bergerak maupun tidak bergerak yang kemudian disahkan oleh para ahli waris yang bersangkutan, bila perlu dinilai harganya dengan uang;

b. menghitung jumlah pengeluaran untuk kepentingan pewaris sesuai dengan Pasal 175 ayat (1) sub a, b, dan c.

(2) Sisa dari pengeluaran dimaksud di atas adalah merupakan harta warisan yang harus dibagikan kepada ahli waris yang berhak.
Pasal 188

Para ahli waris baik secara bersama-sama atau perseorangan dapat mengajukan permintaan kepada ahli waris yang lain untuk melakukan pembagian harta warisan. Bila ada diantara ahli waris yang tidak menyetujui permintaan itu, maka yang bersangkutan dapat mengajukan gugatan melalui Pengadilan Agama untuk dilakukan pembagian warisan.

Pasal 189

(1) Bila warisan yang akan dibagi berupa lahan pertanian yang luasnya kurang dari 2 hektar, supaya dipertahankan kesatuannya sebagaimana semula, dan dimanfaatkan untuk kepentingan bersama para ahli waris yang bersangkutan.

(2) Bila ketentuan tersebut pada ayat (1) pasal ini tidak dimungkinkan karena di antara para ahli waris yang bersangkutan ada yang memerlukan uang, maka lahan tersebut dapat dimiliki oleh seorang atau lebih ahli waris yang dengan cara membayar harganya kepada ahli waris yang berhak sesuai dengan bagiannya masing-masing.

\section{Pasal 190}

Bagi pewaris yang beristeri lebih dari seorang, maka masing-masing isteri berhak mendapat bagian atas gono-gini dari rumah tangga dengan suaminya, sedangkan keseluruhan bagian pewaris adalah menjadi hak para ahli warisnya.

\section{Pasal 191}

Bila pewaris tidak meninggalkanahli waris sama sekali atau ahli warisnya tidak diketahui ada atau tidaknya, maka harta tersebut atas putusan Pengadilan Agama diserahkan penguasaannya kepada Baitul Mal untuk kepentingan Agama Islam dan kesejahteraan umum.

Pasal 192

Apabila dalam pembagian harta warisan di antara para ahli warisnya Dzawil furud menunjukkan bahwa angka pembilang lebih besar dari angka penyebut, maka angka penyebut dinaikkan sesuai dengan angka pembilang, dan baru sesudah itu harta warisnya dibagi secara aul menutu angka pembilang.

\section{Pasal 193}

Apabila dalam pembarian harta warisan di antara para ahli waris Dzawil furud menunjukkan bahwa angka pembilang lebih kecil dari angka penyebut, sedangkan tidak ada ahli waris asabah, maka 
pembagian harta warisan tersebut dilakukan secara rad, yaitu sesuai dengan hak masingmasing ahli waris sedang sisanya dibagi berimbang di antara mereka.

\section{Perkembangan Hukum Kewarisan Islam Dalam Kompilasi Hukum Islam Di Banding Dengan Kewarisan Dalam Fiqih}

1. Bentuk-Bentuk Perkembangan Hukum Kewarisan Dalam Kompilasi Hukum Islam (KHI)

Menurut pandangan para ahli usul fikih bahwa al-Qur'an dan Sunnah Rasulullah di samping menunjukkan hukum dengan bunyi bahasanya, juga dengan "ruh syar'i" atau "maqashid al-syari'ah". Lewat maqashid al-syari'ah inilah ayat-ayat dan Hadits-hadits hukum yang secara kuantitatif sangat terbatas jumlahnya dapat dikembangkan untuk menjawab permasalahanpermasalahanyang secara kajian kebahasaan tidak tertampung dalam al-Qur'an dan Sunnah. Pengembangan itu dilakukan dengan menggunakan metode istimbath seperti dengan qiyas, istihsan,maslahah-mursalah dan 'uirf, yang pada sisi lain juga disebut sebagai dalil. ${ }^{11}$

Atas dasar hal tersebut maka menciptakan perkembangan kewarisan dalam Kompilasi Hukum Islam antara lain:

a. Pasal 171 sub e yang berbunyi "Harta warisan adalah harta bawaan ditambah bagian dari harta bersama setelah digunakan untuk keperlaun pewaris selama sakit sampai meninggalnya, biaya pengurusan jenazah (tajhiz) pembayaran hutang dan pemberian untuk kerabat. "

b. Pasal 176 antara lain menyatakan bahwa bagian waris anak laki-laki adalah dua berbanding satu dengan anak perempuan. Namun pasal 299 (yang merupakan ketentuan penutup) menyatakan bahwa dalam menyelesaikan perkara-perkara yang diajukan kepadanya, hakim wajib memperhatikan dengan sungguh-sungguh nilai-nilai hukum yang hidup dalam masyarakat sehingga putusannya sesuai dengan rasa keadilan. Dan hal itu sudah sering dilakukan oleh pengadilan Indonesia, dengan tidak melaksanakan pembagian warisan berdasarkan prinsip anak

\footnotetext{
${ }^{11}$ A. Khisni, 2016, Perkembangan Pemikiran Hukum Islam (Ikhtiyar Pendidikan Doktor Membekali Calon Mujtahidmenggali Maqashid al-Syariah untuk Mewujudkan Hukum Islam yang Kontekstual), Cetakan Kelima, UNISSULA PRESS Semarang, Semarang, h. 38.
}

laki-laki mendapat bagian dua sedang perempuan satu. ${ }^{12}$

c. Pasal 177 tentang bagian ayah. Dalam pasal ini dirumuskan bahwa ayah mendapat $1 / 3$ bagian dari apabila pewaris tidak meninggalkan anak. Tetapi apabila ada anak, maka ayah mendapat $1 / 6$ bagian.

d. Pasala 184 tentang perdamaian dalam pembagian warisan.

e. Pasal 184 tentang pengangkatan wali.

f. Pasal 185 tentang ahli waris pengganti.

g. Pasal 189 tentang pemeliharaan keutuhan dan kesatuan lahan pertanian yang luasnya kurang dari 2 (dua) hektar, supaya dipertahankan kesatuannya sebagaimana semula.

h. Pasal 209 menyatakan bahwa ayah angkat berhak ikut menerima warisan harta peninggalan anak angkatnya.

i. Hukum kewarisan Islam di Indonesia mengakui lembaga Gono-Gini, sedangkan dalam hukum Islam tidak ada. ${ }^{13}$

Perkembangan hukum Islam tersebut mengunakan metode penerapan hukum lewat maqashid al-syariah dalam praktek -praktek istimbath tersebut, yaitu praktek qiyas, istihsan, dan istislah (maslahah-mursalah), dan lainnya seperti istihsab, sadd al-zariah, dan 'urf (adatistiadat) di samping disebut sebagai metode penetapan hokum lewat maqashid al-syari'ah, juga oleh sebagian besar ulama usul fikih disebut sebagai dalil pendukung. ${ }^{14}$

2. Perbandingan Hukum Kewarisan Dalam Kompilasi Hukum Islam Dengan Hukum Kewarisan Dalam Fiqih

Adapun bentuk-bentuk perkembangan kewarisan dalam Kompilasi Hukum Islam antara lain:

1) Pasal 171 sub e yang berbunyi "Harta warisan adalah harta bawaan ditambah bagian dan harta bersama setelah digunakan untuk keperluan pewaris selama sakit sampai meninggalnya, biaya pengurusan jenazah (tajhiz) pembayaran hutang dan pemberian untuk kerabat."

Di dalam pasal tersebut terungkap bahwa harta bersama itu terpisah dari harta pribadi masing-masing. Bahkan dalam perkawinan poligini $\neg$ perkawinan serial, wujud

12 Munawir Sadzali, Relevansi Hukum Keluarga Islam dengan Kebutuhan Masa Kini, dalam Amrullah Ahmad, 1996, Dimensi Hukum Islam dalam Sistem Hukum Nasional. Cet. I Gema Insani Press, ; Jakarta, h. 225.

13 Ibid.

14 A. Khisni, Op.Cit, h. 42 
harta bersama itu terpisah antara suami dengan masing-masing isteri. Sementara dalam al-Qur'an dan al-Hadits, masalah ini tidak dijumpai nashnya secara pasti. Dalam literatur lama fiqh Islam tidak dijumpai pembahasan mengenai harta bersama. Ilmu fiqh cenderung mengabaikan masalah ini sehingga menimbulkan kesan bahwa isteri tidak berperan dalam pembinaan rumah tangga, termasuk aspek financialnya. ${ }^{15}$

Dedikasi seorang isteri telah berubah di zaman kita hari ini, hal ini merupakan adat dan kebiasaan yang sudah mengakar di dalam masyarakat kita. Jadi, dalam membina rumah tangga selain menjalankan ketentuanketentuan hukum yang normatif, kita tidak dapat mengabaikan pula peranan adat dan tradisi yang pada akhirnya dapat direalisasikan sebagai hukum. Maka konsep harta bersama ini sangat urgen sekali untuk dimasukkan ke dalam Kompilasi sebagai suatu ketentuan hukum di Indonesia. Hasil ijtihad (fiqh) ini, sebagai suatu produk hukum yang diambil dengan menggunakan metodologi urf dan tentu saja bertujuan mashlahat. ${ }^{16}$

2) Pasal 176 menyatakan bahwa bagian waris anak laki-laki adalah dua berbanding satu dengan anak perempuan. Namun pasal 229 (yang merupakan ketentuan penutup) menyatakan bahwa dalam menyeiesaikan perkara-perkara yang diajukan kepadanya, hakim wajib memperhatikan dengan sungguhsungguh nilai-nilai hukum yang hidup dalam masyarakat sehingga putusannya sesuai dengan rasa keadilan. Dan hal itu sudah sering dilakukan oleh pengadilan Indonesia, dengan tidak melaksanakan pembagian warisan berdasarkan prinsip anak laki-laki mendapat bagian dua sedang perempuan satu. ${ }^{17} \mathrm{Hal}$ ini lebih bertujuan pada pelestarian adat dan tradisi putusan hukum yang hidup di Indonesia, ketimbang nilai-nilai syari'at Islam.

3) Pasal 177 tentang bagian ayah. Dalam pasal ini dirumuskan bahwa ayah mendapat $1 / 3$ bagian dari apabila pewaris tidak meninggalkan anak. Tetapi apabila ada anak, maka ayah mendapat $1 / 6$ bagian. Ketentuan pasal ini tidak terdapat dalam al-Qur'an (surat al-Nisa: 11) dan ijma ulama yang nienentukan bagian ayah dengan

15 A. Wasit Aulawi, 1981,Hukum Perkawinan di Indonesia, Bulan Bintang, Jakarta, h. 59.

16 Ibid. h. 60.

17 Ibid. h. 224. cara 'ashobah apabila yang meninggal dunia tidak meninggalkan anak.

4) Pasal 183 tentang perdamaian dalam pembagian warisan. Pasal ini membuka peluang adanya pembagian warisan dalam porsi yang sama (1:1) antara anak laki-laki dan anak perempuan yang menyimpang dari pasal 176 yang mengatur ketentuan anak laki-laki dan anak perempuan.

5) Pasal 184 tentang pengangkatan wali.

6) Pasal 185 tentang ahli waris pengganti. Walaupun hal ini jelas tidak dimaksudkan mengangkat seorang bukan ahli waris menjadi ahli waris, karena tentu hal itu bertentangan dengan hukum kewarisan Islam yang berasaskan ijbari. $^{18}$

7) Pasal 189 tentang pemeliharaan keutuhan dan kesatuan lahan pertanian yang luasnya kurang dari 2 (dua) hektar, supaya dipertahankan kesatuannya sebagaimana semula. Sedangkan bagi ahli waris yang membutuhkan uang atau modal, maka bisa dilakukan dengan cara mengganti harga bagian dari harta warisan yang didapatnya. Pola pembagian ini sebenarnya bertentangan pula dengan asas ijbari. asas ijbari itu mengandung artin bahwa perpindahan hak milik dan seorang muwarits kepada orang lain (ahli waris) berlaku dengan sendiri menurut ketentuan Allah tanpa tergantung pada kehendak muwarits atau ahli waris.

8) Pasal 209 menyatakan bahwa ayah angkat berhak ikut menerima warisan harta peninggalan anak angkatnya. Demikian juga sebaliknya, anak angkat berhak ikut menerima warisan harta peninggalan ayah angkatnya. Kalau mereka tidak menerima wasiat, diberi wasiat wajibah sebanyak-banyaknya $1 / 3$ dari harta warisan anak atau orang tua angkatnya. Padahal, dalam hukum Islam, tidak ada anak dan orang tua angkat menerima warisan.

9) Hukum kewarisan Islam di Indonesia mengakui lembaga Gono-Gini, sedangkan dalam hukum Islam tidak ada. ${ }^{19}$

3. Perkembangan Hukum Kewarisan Islam Dalam Praktek Putusan Pengadilan Agama

Dasar Hukum Kompilasi Hukum Islam di Indonesia adalah intruksi Presiden No. 1 Tahun 1991 tanggla 10 Juni 1991. Menurut Ismail Suny, sudah jelas bahwa dalam bidang perkawinan,

18 Ibid. h. 63

19 Munawir Sadzali, Op. Cit. 225. 
kewarisan, dan wakaf bagi pemeluk-pemeluk Islam telah ditetapkan oleh Undang-undang yang berlaku dalam hukum Islam, aritnya, bahwa bagi masyarakat muslim Indonesia yang harus dijasikan pegangan hukum itu adalah Kompilasi Hukum Islam dalam setiap penyelesaian-penyelesaian masalah perkawian, kewarisan, dan wakaf, dan itu adalah hukum Islam yang sudah dilegalisi oleh Undang-undang. ${ }^{20}$ Dan selanjutnya ia mengatakan bahwa Intruksi Presiden tersebut itu dasar hukumya adalah pasal 4 ayat (1) Undang-Undang Dasar 1945, yaitu kekuasaan Presiden atau Intruksi Presiden, kedudukan hukumnya adalah sama. $^{21}$ Karena itu pembicaraan mengenai kedudukan pompilasi tidak mungkin dilepaskan dari Intruksi Presiden dimaksud.

Lebih lanjut dalam diktum Keputusan Menreti Agama tanggla 22 juli 1991 No. 154 Tahun 1991 disebutkan, bahwa:

Pertama : Seluruh Instansi Departemen Agama dan Instansi Pemerintah lainynya yang terkait yang menyebarluaskan Kompilasi Hukum Islam dibidang Hukum Perkawinan, Kewarisan, dan Kewakafan sebagaimana dimaksud dalam dictum pertama Intruksi Presiden Republik Indonesia Nomor 1 tahun 1991 tanggal 10 juni 1991 untk digunakan oleh Instansi pemerintah dan masyarakat yang memerlukannya dalam menyelesaikan masalah-maslah dibidang tersebut.

Kedua : Seluruh lingkungan instansi tersebut dalam dictum pertama, dalam menyelesaikan masalah-masalah dibidang hukum perkawinan, kewarisan, dan kewakafan sedapat mungkin menerapkan Kompilasi Hukum Islam tersebut disamping peraturan perundangundangan lainnya.

Ketiga : Direktur Jenderal Pembinaan Kelembagaan Agama Islam dan Direktur Bimbingan Masyarakat Islam dan Urusan Haji mengkoordinasikan pelaksanaan Keputusan Menteri Agama Republik Indonesia ini dalam bidang tugasnya masing-masing.

20 Ismail Suny, Kedudukan Hukum Islam dalam Sistem Ketatanegaraan Indonesia, dalam Eddi Rudiana Arief, et. 1991, A/ "Hukum Islam di Indonesia, Perkembangan dan Pembentukkan, Remaja Rosdakarya, Bandung, h. 44.

21 Ibid, h. 44
Keempat : Keputusan ini mulai berlaku sejak diterpakannya. ${ }^{22}$

Satu hal yang perlu perhatian dari Keputusan Menteri Agama ini ialah pada diktum bagian kedua yang berkaitan dengan kedudukan kompilasi yang intinya agar supaya seluruh lingkungan Instansi (dalam kasus ini terutama sekali dimaksud tentunya adalah Instansi Peradilan Agama) agar "sedapat mungkin menerapkan Kompilasi Hukum Islam tersebut di samping peraturan perundangundangan lainnya". Kata-kata "sedapat mungkin" dalam Keputusan Menteri Agama ini kiranya mempunyai kaitan cukup erat dengan kata-kata "dapat digunakan" dalam Instruksi Presiden No. 1 Tahun 1991 sebagaimana dikemukakan di atas,dan juga harus diartikan bukan dalam artian kompilasi hanya dipakai kalau kedaan memungkinkan akan tetapi sebagai suatu anjuran untuk lebih menggunakan kompilasi ini dalam penyelesaian sengketa-sengketa perkawinan, kewarisan, dan perwakafan yang terjadi di kalangan umat Islam.

Dengan demikian, khusus menyangkut fungsi pelaksanaan kompilasi ini tentunya masih diperlukan petunjuk teknis berkenaan dengan bagaimana seharusnya Kompilasi Hukum Islam ini seharusnya dilaksanakan oleh jajaran aparatur Peradilan Agama sehingga mereka tidak mengalami kesulitan dalam pelaksanaannya. Melalui petunjuk pelaksanaan ini diharapkan akan dapat diberikan kejelasan mengenai bagaimana kedudukan dan fungsi Kompilasi Hukum Islam dalam praktik penyelesaian perkara.

Apabila kita berasumsi tentang Instruksi Presiden dan Keputusan Menteri Agama menyangkut kompilasi ini mempunyai kedudukan sebagai "pedoman" dalam artian sebagai sesuatu petunjuk bagi para hakim Peradilan Agaman dalam memutus dan menyelesaikan perkara, maka kedudukannya adalah tergantung sepenuhnya dari para Hakim dimaksud untuk menuangkannya dalam keputusan-keputusan mereka masingmasing sehingga kompilasi ini akan terwujud dan mempunyai makna serta landasan yang kokoh dalam yurisprudensi Peradilan Agama. Dengan cara demikian, maka Peradilan Agama tidak hanya berkewajiban menerapkan ketentuan-ketentuan yang sudah digariskan dalam kompilasi, akan tetapi justru mempunya peranan yang lebih besar lagi untuk memperkembangkan dan sekaligus

H. Abdurrahman, 1992, Kompilasi Hukum Islam di Indonesia, Akademika Pressindo, Jakarta, h.56. 
melengkapinya melalui yurisprudensi yang dibuatnya. ${ }^{23}$

\section{PENUTUP}

\section{Simpulan}

a. Formulasi Hukum Kewarisan Islam Dalam Fiqih Dan Kompilasi Hukum Islam

1) Formulasi Hukum Kewarisan Islam Dalam Fiqih. Formulasi hukum kewarisan Islam dalam fiqih mendasarkan pada al quran dan al hadist yaitu :

a) Al quran, QS. An-nisa (4): 7, QS. An-nisa (4): 11, QS. An-nisa (4): 12, QS. An-nisa (4): 33, QS. An-nisa (4): 176, QS. Alanfal (8): 75,

b) Hadist Rasulullah SAW

- Hadist Nabi dari Ibn Abbas menurut riwayat Al-Bukhari "Dari Ibnu Abbas dia berkata: Rasulullah bersabda: berikan bagian-bagiam warisan kepada ahli warisnya, selebihnya kepada laki-laki yang dekat".

- Hadist Nabi dari Jabir Bin 'Abdillah yang berbunyi: Dari Jabir Bin 'Abdillah berkata: janda Sa'ad datang kepada Rasulallah SAW, bersama dua anak perempuannya. Lalu ia berkata: "Ya Rasulallah, ini dua anak perempuan Sa'ad yang telah gugur secara syahid bersamamu di perang Uhud. Paman mereka mengambil harta peninggalan ayah mereka dan tidak memberikan apa-apa untuk mereka. Keduanya tidak dapat kawan tanpa harta". Nabi berkata: "Allah akan menetapkan hukum dalam kejadian ini". Kemudian ayat-ayat tentang kewarisan. Nabi memanggil si paman dan berkata: "Berikan dua pertiga untuk untuk dua orang anak Sa'ad, seperlapan untuk istri Sa'ad dan selebihnya ambil untukmu".

2) Formulasi hukum kewarisan Islam dalam Kompilasi Hukum Islam di atur dalam Pasal 171 sampai dengan Pasal 193.

b. Perkembangan hukum kewarisan Islam dalam Kompilasi Hukum Islam di banding dengan kewarisan dalam fiqih yaitu banyak memasukkan unsur-unsur hukum adat dan kepentingan-kepentingan yang dibutuhkan masyarakat Indonesia masa sekarang, maka banyak bentuk-bentuk hukum kewarisan yang belum tertuang dalam fiqh konvensional (fiqh al-mawarits), namun hal itu telah termuat dan terkodifikasikan dalam hukum kewarisan Kompilasi Hukum Islam, antara lain: pasal 171 tentang harta bersama, pasal 177 tentang pembagian ayah secara 'ashabah, pasal 209 yang menyatakan bahwa ayah angkat dan anak angkat menerima warisan, dan bila mereka tidak menerima wasiat, maka berhak menerima wasiat wajibah dan Kopilasi Hukum Islam pun mengakui harta gono-gini padahal fiqh tidak mengakui;

c. Perkembangan hukum kewarisan Islam dalam praktek putusan pengadilan agama di Indonesia hal ini tidak lepas dari Kompilasi Hukum Islam merupakan intruksi Presiden No. 1 Tahun 1991 tanggla 10 Juni 1991, sehingga perkawinan, kewarisan, dan wakaf bagi pemeluk-pemeluk Islam telah ditetapkan sehingga dapat dijadikan pengadilan agama sebagai "pedoman" dalam artian sebagai sesuatu petunjuk bagi para hakim Peradilan Agaman dalam memutus dan menyelesaikan perkara, maka kedudukannya adalah tergantung sepenuhnya dari para Hakim dimaksud untuk menuangkannya dalam keputusan-keputusan mereka masing-masing sehingga kompilasi ini akan terwujud dan mempunyai makna serta landasan yang kokoh dalam yurisprudensi Peradilan Agama. Dengan cara demikian, maka Peradilan Agama tidak hanya berkewajiban menerapkan ketentuanketentuan yang sudah digariskan dalam kompilasi, akan tetapi justru mempunya peranan yang lebih besar lagi untuk memperkembangkan dan sekaligus melengkapinya melalui yurisprudensi yang dibuatnya.

\section{Saran}

a. Dalam perubahan dari fiqih konvensional ke KHI harus tetap mengunakan kaidah kaidah fiqih yang tidak bertentangan dan sesuai dengan keadaan bangsa Indonesia.

b. Berubahnya zaman serta kebutuhan masyarakat Indonesia terhadap kepastian hukum yang akan di anutnya, sehingga di harapkan mujtahid mujtahid untuk selalu melakukan pembaharuan hukum

c. Semua pebaharuan hukum di KHI dapat dijadikan hukum terapan (materiii) bagi instansi Perintah (Pengdilan Agama) dan masyarakat Indonesia dalam menyelesaikan perkara-perkara kewarisan.

\footnotetext{
${ }^{23}$ Ibid. h.53-58
} 


\section{DAFTAR PUSTAKA}

Abdul Gani Abdullah, 1992, Pengantar Kompilasi Hukum Islam dalam Tata Hukum Indonesia,Gema Insani Press, Jakarta.

Abdullah An-Naim, 1994, Toward an Islamic Reformation Cil Liberties, Human Rights and International Law(diterjemahkan oleh Ahmad Suaedy dan Amiruddin Arrani), Dekonstruksi Syari'ah, LkiS, Yogyakarta

Ahmad Hasan, 1994, The early Development of Islamic Yurisprudence (terj.),Kitab Bhavan, New Delhi.

Al-Hafidh Ibnu Hajar AL-Asqalani, 1995, Bulughul Maram, Ali, Terjemah Bulughul Maram, Mutiara Ilmu, Surabaya.

A. Djazuli, Beberapa Aspek Pengembangan Hukum Islam di Indonesia, dalam Eddi Rudiana Arief, et. Al. (ED). 1991, Hukum Islam di Indonesia Pemikiran dan Praktek, Rosdakarya, Bandung.

A. Khisni, 2016, Perkembangan Pemikiran Hukum Islam (Ikhtiyar Pendidikan Doktor Membekali Calon Mujtahidmenggali

Munawir Sadzali, Relevansi Hukum Keluarga Islam dengan Kebutuhan Masa Kini, dalam Amrullah Ahmad, 1996, Dimensi Hukum Islam dalam Sistem Hukum Nasional. Cet. I Gema Insani Press, ; Jakarta.
Maqashid al-Syariah untuk Mewujudkan Hukum Islam yang Kontekstual), Cetakan Kelima, UNISSULA PRESS Semarang, Semarang.

A. Wasit Aulawi, 1981,Hukum Perkawinan di Indonesia, Bulan Bintang, Jakarta.

Bagir Manan, 1995, Pertumbuhan dan Perkembangan Konstitusi Suatu Negara, Mandar Maju Bandung.

Cik Hasan Bisri, 1996, Dimensi-dimensi Kompilasi Hukum Islam, Ulul Albab Press, Bandung.

Fazlur Rahman, 1994, Islam (Terj.), Salman ITB, Bandung.

H. Abdurrahman, 1992, Kompilasi Hukum Islam di Indonesia, Akademika Pressindo, Jakarta.

Ismail Suny, Kedudukan Hukum Islam dalam Sistem Ketatanegaraan Indonesia, dalam Eddi Rudiana Arief, et. 1991, A/ "Hukum Islam di Indonesia, Perkembangan dan Pembentukkan, Remaja Rosdakarya, Bandung.

Jabir Bin Abu Dawud, al-Tirmizi, Ibnu Majjah dan Ahmad, 1952, Sunanu Abi Dawud II, Mustafa al Babiy, Cairo. 